\title{
POLA DISTRIBUSI RANTAI PASOK JARINGAN MADU HUTAN SUMBAWA (JMHS) DI KABUPATEN SUMBAWA, NUSA TENGGARA BARAT
}

\author{
Qashiratuttarafi' ${ }^{1)}$, Andriyono Kilat Adhi' ${ }^{2)}$ dan Wahyu Budi Priatna ${ }^{3)}$ \\ ${ }^{1)}$ Departemen Agribisnis, Fakultas Ekonomi dan Manajemen, Institut Pertanian Bogor \\ ${ }^{2,3)}$ Departemen Agribisnis, Fakultas Ekonomi dan Manajemen, Institut Pertanian Bogor \\ ${ }^{1)}$ qashiratuttarafi@gmail.com
}

\begin{abstract}
This study was aimed to analyze the supply chain distribution patterns of forest honey in the West Sumbawa through Sumbawa Forest Honey Network or Jaringan Madu Hutan Sumbawa (JMHS) using descriptive qualitative data. This study uses a supply chain distribution pattern approach based on the product, financial and information flow. In the product flow, honey is harvested by honey hunters in the forest and assembled to a group leader. Then, honey is handed over to JMHS and marketed at Rumah Madu” (Honey House). The forest honey harvest season in Sumbawa is between August-December. Honey hunters can harvest 15-20 liters of honey per hunter in one hunting day. In financial flow, we observed that the pricing of honey is decided by JMHS according to the market price and the harvest season. Honey price from the hunter is ranging from 60,000 - 75,000 IDR per $660 \mathrm{ml}$ bottle. The purchasing price of honey by JMHS is 65,000-85.000 IDR per $660 \mathrm{ml}$ bottle and after the packaging by JMHS, honey is marketed to the last consumers with a selling price of 110,000 IDR per $500 \mathrm{ml}$. The information flows in both directions. The group of honey hunters inform to JMHS about the locations of honey as well as the amount of harvested. In the JMHS side, they distribute information of the classification and quality of honey, provide the good harvest training and information on honey price to hunters.
\end{abstract}

Keyword(s): forest honey, distribution patterns, JMHS.

\begin{abstract}
ABSTRAK
Penelitian ini bertujuan untuk mengetahui kondisi pola distribusi rantai pasok madu hutan di Kabupaten Sumbawa melalui Jaringan Madu Hutan Sumbawa (JMHS) yang menggunakan data desktiptif kualitatif. Penelitian ini menggunakan pendekatan Pola distribusi rantai pasok oleh Nurmalina (2014) berdasarkan pada aliran produk, aliran uang dan aliran informasi. Dalam aliran produk, madu dipanen oleh pemburu madu di hutan dan dikumpulkan kepada ketua kelompok. Kemudian, madu diserahkan ke JMHS dan dipasarkan di Rumah Madu. Musim panen madu hutan di Kabupaten Sumbawa antara bulan Agustus-Desember. Pemburu dapat memanen 15-20 liter madu perorang dalam satu kali berburu. Dalam aliran keuangan, kami mengamati bahwa harga madu ditentukan oleh JMHS sesuai dengan harga pasar dan musim panen. Harga madu dari pemburu berkisar antara Rp 60.000 - 75.000 perbotol $660 \mathrm{ml}$. Harga pembelian madu oleh JMHS adalah Rp 65.000-85.000 per botol $660 \mathrm{ml}$ dan setelah dikemas oleh JMHS, madu dipasarkan ke konsumen akhir dengan harga jual Rp 110.000 per $500 \mathrm{ml}$. Aliran informasi, kami menemukan bahwa informasi mengalir dua arah. Kelompok pemburu menginformasikan ke JMHS mengenai lokasi madu serta jumlah madu yang dipanen. JMHS memberikan informasi mengenai klasifikasi dan kualitas madu, memberikan informasi pelatihan panen yang baik dan informasi harga madu pada pemburu.
\end{abstract}

Kata kunci: madu hutan, pola distribusi, JMHS 


\section{PENDAHULUAN}

Madu merupakan salah satu produk Hasil Hutan Bukan Kayu (HHBK) yang telah lama dimanfaatkan di Indonesia (Moko, 2008). Madu berasal dari fermentasi nektar bunga yang dikumpulkan oleh lebah dan kemudian diproses menjadi zat kental manis (Murtidjo, 1991). Terdapat dua cara untuk memperoleh madu yaitu dengan cara perburuan madu (honey hunter) dan dengan cara melakukan budidaya lebah madu (apiculture/beekeeping) (Hilmi et al 2011). Menurut data FAO (20112015), jumlah impor madu di Indonesia yaitu berkisar antara 70.217 - 2.243.474 $\mathrm{Kg}$ /tahun. Sedangkan ekspor madu Indonesia berkisar antara 2.962 615.584 Kg/tahun.

Produksi madu yang ada di Indonesia umumnya diperoleh dari tiga jenis lebah madu yaitu Apis Dorsata (lebah hutan), Apis Cerana (lebah lokal) dan Apismellifera (lebah Eropa) (Hadisoesilo 2001). Madu yang didapatkan dari ketiga jenis lebah madu ini umumnya berupa madu hutan/liar sebanyak $75 \%$ dan madu hasil budidaya sebanyak $25 \%$ dari total produksi madu nasional (Novandra dan Widnyana, 2013).

Jaringan Madu Hutan Indonesia (JMHI) merupakan sebuah organisasi yang fokus pada pengembangan madu hutan. JMHI memiliki jaringan kerja mulai dari pulau Sumatera, Jawa, Kalimantan, Sumbawa hingga ke Sulawesi (Julmansyah, 2010). Jumlah produksi madu hutan Indonesia berdasarkan data produksi madu JMHI sangat berfluktuatif. Produksi madu Indonesia berkisar antara 15.000 $116.605 \mathrm{Kg} /$ tahun dalam 5 tahun terakhir (2014-2018).
Salah satu organisasi usaha yang bergerak melestarikan usaha madu hutan di Kabupaten Sumbawa yaitu Jaringan Madu Hutan Sumbawa (JMHS) (Julmansyah 2010). Organisasi JMHS merupakan salah satu anggota jaringan dibawah naugan JMHI. JMHS berpotensi untuk dikembangkan karena kebutuhan akan madu hutan terus meningkat. Umumnya masyarakat di Sumbawa melakukan perburuan madu hutan sebagai usaha utama. Sementara usaha madu hutan anggota JMHS telah dikelola secara khusus dengan aktivitas memanen yang lebih baik (Julmansyah 2010). Data produksi madu JMHS (2017), menunjukkan bahwa dari tahun 2015-2017 produksi madu hutan mengalami penurunan drastis yaitu sebesar 370.624 - $76.932 \mathrm{Kg}$.

Menurunnya produksi madu JMHS berdampak pada kuantitas dan kualitas produksi madu JMHS. Selain itu, perbedaan harga pada setiap lokasi pengambilan madu yang berbeda serta Informasi yang belum merata menjadi permasalahan pada organisasi JMHS. Permasalahan tersebut menyebabkan lemahnya rantai pasok JMHS. Proses bisnis rantai pasok menggambarkan seluruh proses yang terjadi di sepanjang rantai pasok JMHS. Proses bisnis rantai pasok dapat dikatakan baik apabila saling terintegrasi antar anggota rantai yang tergabung di dalamnya (Syakur 2017).

\section{KERANGKA PEMIKIRAN}

Rantai pasok atau supply chain merupakan suatu konsep dimana terdapat sistem pengaturan yang berkaitan dengan pola distribusi yang menggambarkan tiga komponen utama rantai pasok yaitu aliran produk, aliran keuangan (finansial) dan aliran 
informasi (Indrajit dan Djokopranoto, 2002).

Rantai pasok adalah keterpaduan antara perencanaan, koordinasi, dan kendali seluruh proses dan aktivitas bisnis dalam rantai pasok untuk memenuhi kebutuhan konsumen dengan biaya yang paling rendah (Chopra dan Meindhl 2007). Adanya pendekatan rantai pasok produk dapat memberikan gambaran ketersediaan produk sebagai pertimbangan pengelolaan supply chain bagi konsumen maupun industry pengolah (Kurniawan. 2014). Melalui rantai pasokan, organisasi dapat membangun kerjasama melalui penciptaan jaringan kerja (network) yang terkoordinasi dalam penyediaan barang maupun jasa bagi konsumen secara efisien (Nurmalina 2014).

Terkait dengan rantai pasok JMHS, terdapat beberapa biaya yang harus dikeluarkan pada setiap pelaku rantai pasok atau stakeholders yang terlibat. Madu yang berasal dari jenis Apis dorsata ini diperoleh secara langsung dari kawasan hutan Sumbawa oleh pemburu madu. Sebelum sampai pada konsumen, akan melewati beberapa pelaku rantai seperti ketua kelompok, koperasi dan outlet pemasaran rumah madu. Pada umumnya koperasi merupakan tempat penampungan madu terbesar JMHS. Koperasi JMHS memasarkan madu untuk memenuhi kebutuhan nasional melalui kerjasama antara JMHS melalui perusahaan mitra JMHI yaitu perusahaan ritel PD. Dian Niaga. Sedangkan untuk memenuhi kebutuhan lokal, JMHS memasarkan madu melalui outlet pemasaran Rumah Madu yang dijual langsung ke konsumen akhir.

Penelitian ini bertujuan untuk menganalisis pola distribusi yang terjadi pada rantai pasok JMHS, berdasarkan tiga aliran utama yaitu aliran produk, aliran finansial dan aliran informasi. Oleh karena itu penelitian mengenai analisis pola distribusi rantai pasok pada JMHS perlu dilakukan.

\section{METODE PENELITIAN}

Penelitian dilakukan pada organisasi Jaringan Madu Hutan Sumbawa (JMHS) di Kabupaten Sumbawa. Pemilihan lokasi penelitian dilakukan secara sengaja (purposive), yaitu dengan cara menentukan tiga kecamatan berdasarkan pertimbangan bahwa daerah tersebut merupakan kawasan daerah Kesatuan Pengolahan Hutan (KPH) dibawah naungan Kementrian Lingkungan Hidup dan Kehutanan sebagai daerah penghasil madu yang mudah dijangkau oleh transportasi dan terdapat anggota Jaringan Madu Hutan Sumbawa (JMHS). Ketiga daerah tersebut terdiri dari KPH Puncak Ngengas Batulanteh di Kecamatan Batu Lanteh, KPH Ropang Lantung di Kecamatan Lantung dan KPH Ampang Pelampang di Kecamatan Plampang. Penelitian dilakukan pada bulan Maret - Mei 2018.

Data yang digunakan dalam penelitian yaitu data primer dan sekunder. Data primer diperoleh dari anggota Jaringan Madu Hutan Sumbawa (JMHS) diantaranya pemburuh madu, ketua kelompok, koperasi, outlet pemasaran Rumah Madu dan semua unit yang terlibat di dalam rantai pasok JMHS. Hal ini bertujuan untuk memperoleh gambaran sistem rantai pasok JMHS dari produsen hingga ke konsumen. Data sekunder diperoleh dari JMHS, JMHI, BKPH terkait, buku, jurnal, artikel, internet, dan literatur lain yang memiliki hubungan dengan topik 
penelitian. Metode penelitian yang digunakan dalam penelitian ini adalah metode survei, yaitu dengan cara melihat kondisi pemasaran yang terjadi di lokasi penelitian menggunakan sistem wawancara. Sehingga aktivitas rantai pasok dapat diamati secara keseluruhan. Penentuan Jumlah responden sebanyak 30 pemburu madu yang dilakukan secara sengaja (purposive sampling) yaitu dengan menentukan 10 orang pemburu madu pada smasing-masing $\mathrm{KPH}$ dan dianggap telah mewakili pengumpulan informasi setelah dilakukan identifikasi adanya mitra kerja dengan JMHS. Penentuan responden pelaku rantai pasok dilakukan dengan menggunakan teknik Snowball Sampling dari pemburu madu mitra berjumlah 2 orang ketua kelompok yang berdomisili di Kecamatan Batulanteh dan Kecamatan Lantung, 2 koperasi JMHS dan 1 outlet pemasaran Rumah Madu. 2) Usaha madu hutan membutuhkan jaringan rantai pasok yang terdiri dari beberapa pelaku usaha. Untuk menjamin keberhasilan penerapan rantai pasok, perlu pemahaman mengenai proses bisnis rantai pasok JMHS. Proses bisnis tersebut memiliki pola distribusi pada 3 aliran utama yang harus dikelola dengan baik, yaitu aliran produk, aliran finansial dan aliran informasi (Nurmalina 2014).

1. Aliran produk madu hutan meliputi Jumlah produksi, arah pemasaran, bentuk penjualan produk, perlakuan produk dan proses distribusi, yang mengalir dimulai dari pemburu madu, supplier bahan baku, perusahaan manufaktur, penjual perantara (intermediaries), lalu berakhir dikonsumen akhir.

2. Aliran uang (finansial) madu hutan meliputi harga jual, harga beli, biaya produksi, modal, keuntungan, biaya pengangkutan, biaya distribusi, penentuan harga, Informasi kartu kredit, syarat-syarat kredit, jadwal pembayaran dalam penetapan kepemilikan dan pengiriman. Aliran uang mengalir berlawanan arah dari konsumen ke perantara lalu ke perusahaan manufaktur dan berakhir di supplier.

3. Aliran informasi yang bergerak dua arah dan terbuka artinya informasi dibutuhkan dari anggota logistik dan informasi tersebut dapat diakses oleh anggota lain, yang meliputi luas area panen, volume penjualan, klasifikasi dan mutu penjualan, perkiraan produksi, ramalan permintaan, transmisi pesanan dan laporan status pesanan.

\section{HASIL DAN PEMBAHASAN}

\section{Struktur Rantai Pasok JMHS}

Struktur rantai pasok JMHS di dianalisis berdasarkan batas jaringan anggota rantai pasok dan mendeskripsikan peran dari setiap anggota. Anggota rantai pasok dalam hal ini adalah para pelaku yang terlibat dalam proses bisnis. JMHS memiliki empat pelaku rantai pasok yaitu pemburu (supplier), ketua kelompok (distributor), koprasi JMHS (wholesaler) dan outlet pemasaran "Rumah Madu"

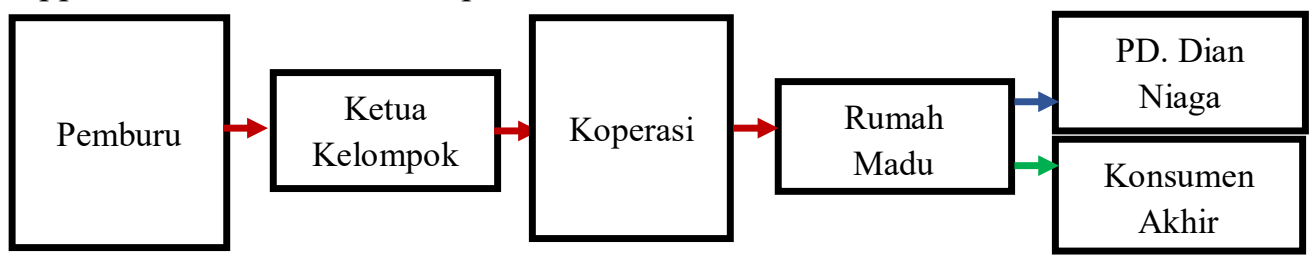

Gambar 1. Struktur Hubungan Rantai Pasok Jaringan Madu Hutan Sumbawa 
(ritel). Struktur hubungan rantai pasok JMHS disajikan dalam Gambar 1 :

Pemburu merupakan anggota rantai pasok yang pertama di dalam rantai pasok JMHS. Pemburu memiliki peran penting dalam rantai pasok dikarenakan kualitas, kuantitas dan keberlanjutan hasil berburu madu sangat ditentukan oleh cara panen pemburu. Sebagian pemburu menerapkan sistem panen lestari dan tidak sedikit pula pemburu memanen dengan cara tradisional sesuai pengalaman turun temurun. Hasil panen madu langsung dijual kepada ketua kelompok. Pemburu mendapat banyak bantuan dari ketua kelompok sehingga timbul rasa saling percaya.

Ketua kelompok merupakan pedagang pengumpul desa pada wilayah kawasan hutan dan telah terdaftar sebagai anggota resmi JMHS. Ketua kelompok memiliki peran untuk mengontrol kualitas madu dan penampungan sementara sebelum disalurkan ke koperasi JMHS. Madu yang telah dikumpulkan kemudian dimasukkan kedalam penampungan madu dengan menggunakan sistem tiris yaitu dengan cara menyaring madu dengan saringan khusus dan membelah sarang lebah menggunakan pisau stainless khusus hingga menghasilkan kualitas madu yang baik. Madu yang telah ditampung selanjutnya disalurkan ke koprasi. Kendala yang dirasakan oleh ketua kelompok yaitu tidak memiliki ruangan steril yang sesuai dengan standar nasional, alat transportasi yang belum memadai yang diakibatkan minimnya modal dan pembayaran yang tidak lancar oleh koperasi.

Koperasi merupakan tempat penampungan madu JMHS dengan kapasitas yang besar. Terdapat dua koperasi JMHS, yaitu koperasi Madu
Hutan Lestari berlokasi di Kecamatan Batulanteh yaitu di desa Batudulang dengan area pengumpulan madu yaitu di kawasan hutan bagian selatan Kabupaten Sumbawa dan koperasi Balong Gama yang berada di Kecamatan Empang Desa Gapit dengan area pengumpulan madu yaitu di kawasan hutan bagian timur Kabupaten Sumbawa. Koprasi JMHS melakukan proses pengemasan menggunakan jerigen 25-30 liter untuk disalurkan ke outlet pemasaran Rumah Madu dan perusahaan retail yang bekerjasama dengan JMHS yaitu PD. Dian Niaga. Koprasi JMHS melakukan aktivitas bisnis hanya dimusim panen madu yaitu pada bulan-bulan tertentu sesuai dengan kalender panen madu yang dimulai pada bulan April dan berakhir pada bulan Desember.

Rumah madu merupakan outlet atau wadah pemasaran JMHS. Lokasi Rumah Madu berada di pusat Kota Sumbawa Besar Kecamatan Sumbawa. Madu yang dipasarkan melalui outlet Rumah Madu berasal dari koperasi. Rumah Madu melakukan kegiatan pengemasan madu menggunakan kemasan botol plastik, botol kaca dan jerigen berukuran 2 liter, 1 liter, $500 \mathrm{ml}$, $250 \mathrm{ml}$ dan $150 \mathrm{ml}$ sesuai permintaan konsumen akhir. Kurangnya pasokan madu dari koprasi pada bulan-bulan tertentu menjadi kendala bagi outlet Rumah Madu untuk beroperasi setiap hari.

\section{Pola Aliran Rantai Pasok JMHS}

JMHS memiliki empat pelaku rantai pasok yaitu pemburu madu, ketua kelompok, koprasi JMHS dan outlet pemasaran "Rumah Madu". Struktur hubungan rantai pasok Jaringan Madu 
Hutan Sumbawa (JMHS) disajikan yaitu koperasi Madu Hutan Lestari dalam Gambar 2 berikut :

dengan kawasan pengumpulan madu di

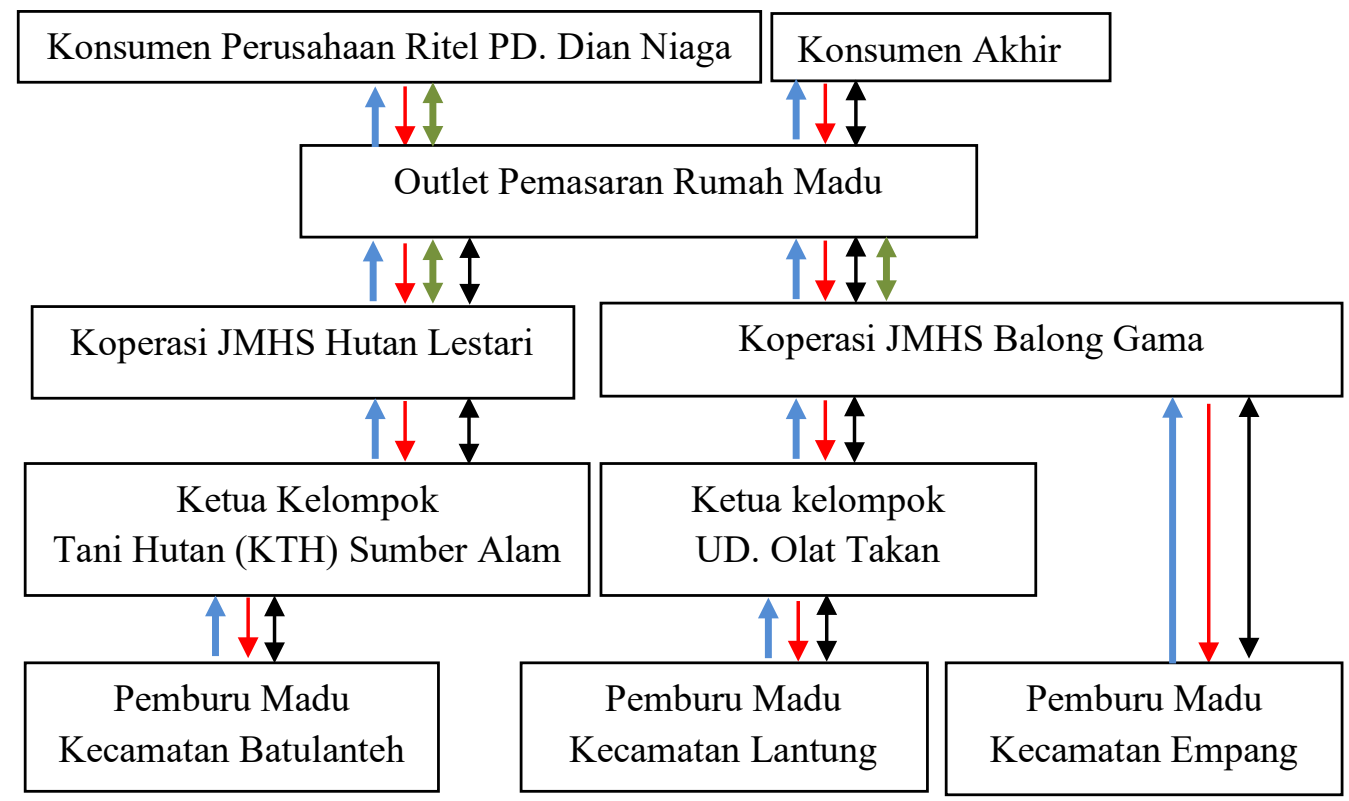

Keterangan :

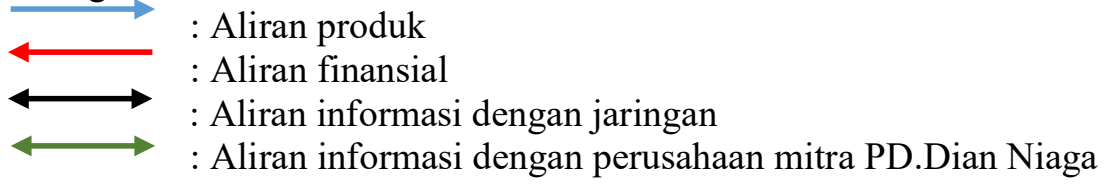

\section{Gambar 2. Struktur hubungan rantai pasok Jaringan Madu Hutan Sumbawa}

Jaringan Madu Hutan Sumbawa (JMHS) memiliki kriteria khusus dalam memilih mitra kerjanya. Terdapat tiga rantai pasok JMHS. Rantai 1 dan 2 melibatkan ketua kelompok dalam proses distribusi madu. sedangkan rantai 3 tidak melibatkan ketua kelompok dalam proses distribusi madu. Pemburu (supplier) JMHS ditemui pada tiga kecamatan yaitu Kecamatan Batulanteh, Kecamatan Lantung dan Kecamatan Empang. Ketua kelompok JMHS berasal dari Kecamatan Batulanteh yaitu ketua Kelompok Tani Hutan (KTH) Sumber Alam dan ketua kelompok UD. Olat Takan yang berasal dari Kecamatan Lantung. JMHS memiliki dua koperasi
Kabupaten Sumbawa bagian Selatan dan koperasi Balong gama dengan kawasan pengambilan madu di Kabupaten Sumbawa bagian Timur.

\section{Aliran Produk}

Secara umum, madu yang dihasilkan oleh pemburu madu di Kabupaten Sumbawa merupakan madu murni hasil hutan yang berasal dari jenis lebah apis dorsata. Pada saat musim panen raya, produksi madu banyak dan melimpah sehingga pemburu madu biasanya mencari madu hampir setiap hari hanya beberapa tempat yang melakukan panen satu minggu sekali 
yaitu pada desa boal Kecamatan Empang, hal ini disebabkan oleh lokasi rumah pemburu tidak terlalu dekat dengan lokasi panen madu. Aliran produk JMHS disajikan dalam Gambar 3 berikut : madu dihitung berdasarkan volume botol air mineral tanggung. Sesuai dengan pengalaman turun temurun, pemburu memperkirakan volume 5 liter madu setara dengan 8-10 botol air mineral tanggung dengan cara

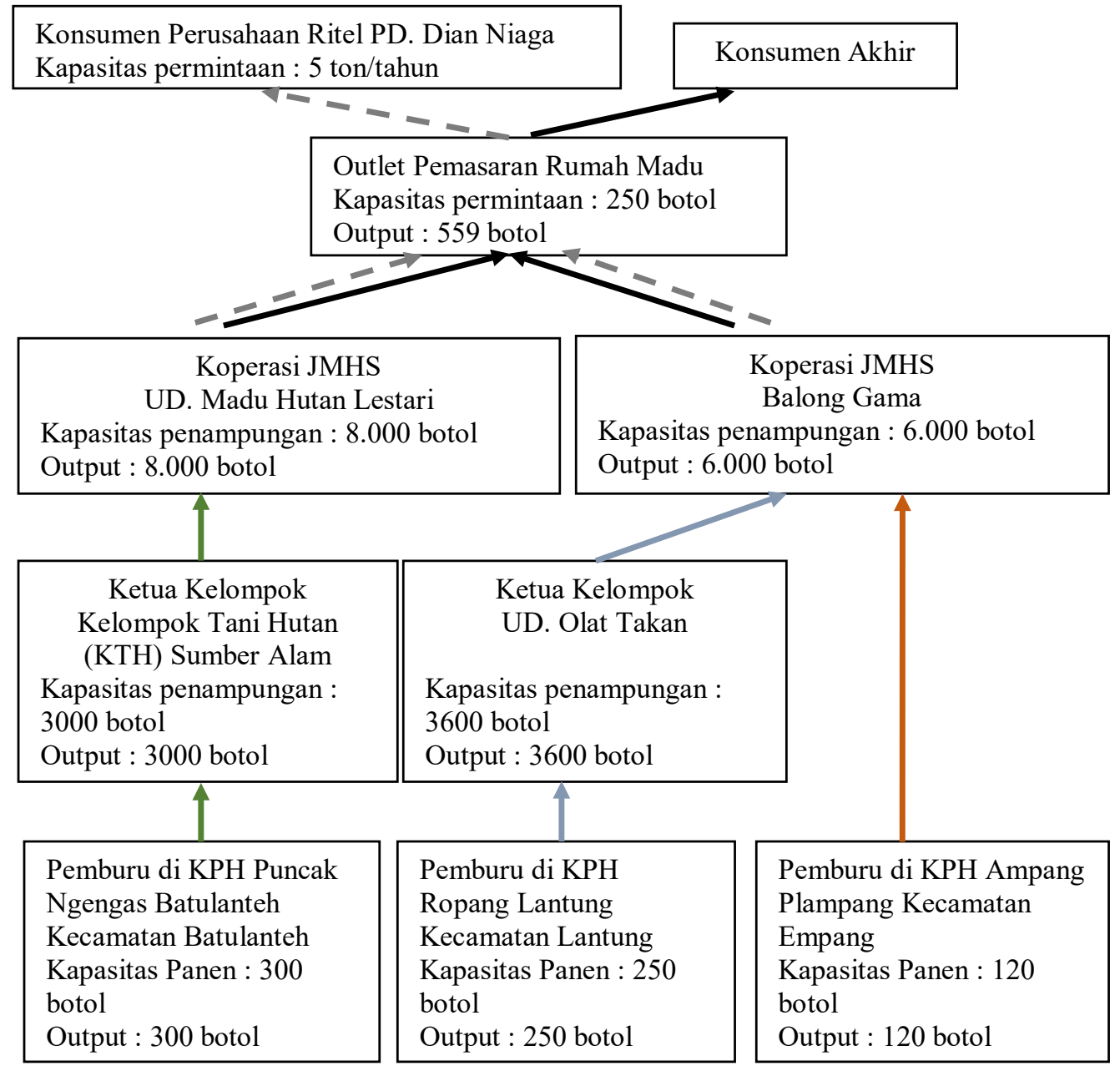

Keterangan :

$\longrightarrow$ : Aliran produk ke jaringan

$-\rightarrow$ : Aliran produk ke perusahaan mitra PD.Dian Niaga

Gambar 3. Aliran produk rantai pasok JMHS

Dalam satu kali panen, masingmasing pemburu mampu membawa pulang madu rata-rata sebanyak 3-4 cerigen 5 liter. Perhitungan penjualan memprediksi rupa cerigen lama dengan warna yang kusam dan sudah mengembung yang dapat menghasilkan 10 botol madu dan cerigen yang masih terlihat baru hanya menghasilkan 8 botol 
madu. Hasil madu yang telah dipanen langsung dijual kepada ketua kelompok anggota JMHS yang ada dimasingmasing daerah tersebut. Namun di desa Boal Kecamatan Empang tidak ditemukan ketua kelompok anggota JMHS dan dekat dengan koperasi JMHS sehingga madu hasil panen di jual langsung ke koperasi JMHS. Namun, secara keseluruhan pemburu madu tidak hanya menjual madu kepada JMHS tetapi juga menjual madu kepada pedagang pengumpul lainnya yang mampu membeli madu diatas harga yang telah ditentukan oleh JMHS.

Ketua kelompok merupakan pedagang pengumpul desa yang telah terdaftar sebagai anggota JMHS. Dari tiga lokasi daerah penelitian hanya dua orang ketua kelompok yang dapat dijumpai yaitu ketua Kelompok Tani Hutan (KTH) Sumber Alam yang berasal dari Kecamatan Batulanteh dan ketua kelompok UD. Olat Takan yang berasal dari Kecamatan Lantung. Kedua ketua kelompok tersebut sudah pernah menghadiri platihan cara memanen madu menggunakan sistem panen lestari dan teknik penyaringan menggunakan sistem tiris. Madu yang dijual berasal dari pemburu madu yang ada disekitar lokasi daerah tersebut. Pada saat panen raya ketua kelompok KTH Sumber Alam mampu menampung madu mencapai 3000 botol dalam sedangkan ketua kelompok UD. Olat Takan mampu menampung madu sebanyak 3600 botol/bulan. Madu yang dijual dalam bentuk madu murni dan diberikan perlakuan dengan cara menyaring madu menggunakan sistem tiris tanpak diperas menggunakan tangan. Selanjutnya madu didistribusikan langsung ke koperasi JMHS. Koperasi JMHS membeli madu kepada ketua kelompok anggota JMHS sekala besar dengan volume madu mencapai 75-100 ton pertahun. Terdapat dua koperasi JMHS yaitu koperasi Madu Hutan Lestari yang berlokasi di desa Batudulang Kecamatan Batulanteh dengan cakupan pengumpulan madu pada wilayah selatan Kabupaten Sumbawa. Kapasitas penampungan madu rata-rata mencapai 48 ton pertahun sesuai dengan musim panen madu dengan rata-rata pengambilan madu perbulan sebesar 8.000 botol. Koperasi kedua yaitu koperasi Balong Gama yang berlokasi di desa Gapit Kecamatan Empang dengan cakupan pengumpulan madu pada wilayah timur Kabupaten Sumbawa. Kapasitas penampungan madu rata-rata mencapai 36 ton pertahun dengan pengambilan madu sebulan sebanyak 6.000 botol. Koperasi JMHS melakukan pengecekan kondisi kadar air dan kemurnian madu menggunakan alat refractometer. Madu yang siap dijual didistribusikan untuk memenuhi permintaan perusahaan ritel PD. Dian Niaga dan untuk memenuhi kebutuhan konsumen akhir yang dipasarkan melalui outlet pemasaran Rumah Madu. Kedua koperasi JMHS melakukan penitipan terlebih dahulu di outet pemasaran Rumah Madu sebelum madu siap dikirim ke ritel.

Outlet pemasaran Rumah Madu merupakan rantai terakhir dari proses distribusi madu. Rumah Madu melakukan aktivitas pengemasan dan pelabelan menggunakan kemasan dengan volume kecil yang bertujuan untuk memenuhi permintaan konsumen akhir seperti masyarakat sekitar, pemerintahan dan wisatawan yang berkunjung ke Sumbawa. Kapasitas permintaan madu oleh Rumah Madu rata-rata mencapai 250 botol perbulan. 


\section{Aliran Finansial}

Biaya produksi yang dikeluarkan oleh pemburu madu hampir tidak ada dikarenan madu diperoleh bebas dari hutan. Pemburu madu hanya mengeluarkan modal bekal menuju lokasi seperti pembelian lauk pauk, rokok, jajan, korek, obat dan binsin. Rata- rata pemburu membentuk kelompok pencari madu berkisar antara 2 hingga 5 orang dan memerlukan modal berangkat menuju hutan sebesar 50.000/orang. Harga pembelian dari pemburu oleh ketua kelompok maupun harga pasar yang berlaku. Aliran finansial JMHS disajikan dalam Gambar 4 berikut :

Harga jual madu hasil panen pemburu madu berbeda-beda tergantung lokasi dan musim panen madu. pemburu madu yang berasal dari Kecamatan Batulanteh menjual madu ke ketua kelompok seharga Rp. 70.000/botol, pemburu madu di Kecamatan Lantung juga menjual kepada ketua kelompok dengan harga Rp. 60.000/botol dan harga jual madu yang dilakukan langsung dari pemburu ke koperasi JMHS di Kecamatan Empang sebesar

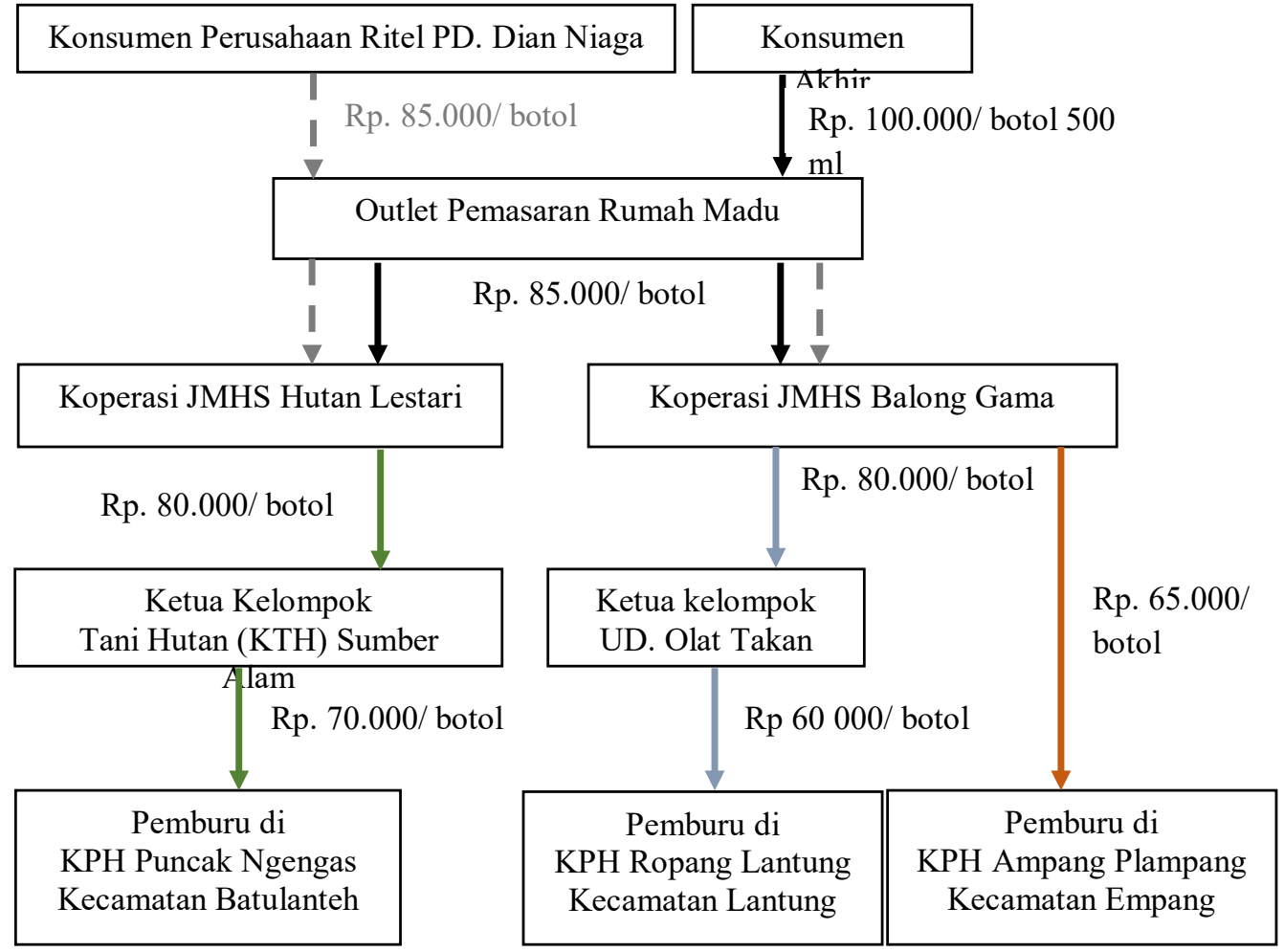

Keterangan :

$\longrightarrow$ : Aliran finansial dari jaringan

$-\rightarrow$ : Aliran finansial perusahaan mitra PD.Dian Niaga

Gambar 4. Aliran finansial rantai pasok JMHS

koperasi JMHS ditentukan oleh JMHS Rp. 65.000. Penentuan harga sesuai hasil rapat internal sesuai dengan disesuaikan dengan kualitas madu dan 
musim panen raya. Jika kualitas madu sangat cair sehingga menghasilkan kadar air yang lebih tinggi, maka harga madu akan dikurangi oleh pemasok. Namun hal ini sangat jarang terjadi disaat panen raya tiba. Pembayaran dilakukan oleh ketua kelompok kepada pemburu madu dengan cara cash atau pembayaran tunai.

Biaya yang dikeluarkan oleh ketua kelompok seperti biaya produksi yaitu modal pembelian madu berkisar antara 10-20 juta perbulannya tergantung musim panen, penyediaan wadah penampungan atau cerigen besar, biaya pemeliharaan, dan biaya operasional yaitu transportasi dan tenaga kerja. Harga pembelian madu dari koperasi JMHS kepada ketua kelompok sama yaitu sebesar Rp. 80.000/botol. Pembayaran yang dilakukan oleh koperasi JMHS kepada ketua kelompok dilakukan dengan cara tunai dan transfer disesuaikan dengan lokasi pengangkutan madu.

Koperasi JMHS mengeluarkan biaya yang lebih besar seperti biaya produksi yaitu modal pembelian madu berkisar 150-300 juta tergantung musim panen, penyediaan wadah penampungan berupa tangki atau cerigen besar, biaya penyusutan madu dan alat, biaya pemeliharaan, dan biaya operasional yaitu transportasi dan tenaga kerja. harga jual koperasi kepada perusahaan ritel yang bermitra seperti PD.Dianiaga dan otlet pemasaran Rumah Madu sebesar 85.000/botol.

Pembayaran yang dilakukan oleh koperasi JMHS kepada ketua kelompok dilakukan dengan cara tunai dan transfer disesuaikan dengan lokasi pengangkutan madu. Pembayaran dengan cara tunai jika madu yang diangkut tidak jauh dengan lokasi kopersi JMHS dengan kapasitas yang kecil, sedangkan pembayaran dengan cara transfer melalui perbankan dilakukan jika lokasi pengangkutan madu jauh dari tempat penampungan koperasi JMHS dan dengan kapasitas besar. Hal ini dilakukan untuk menghindari resiko terjadinya kejahatan saat diperjalanan yang cukup jauh. Selain itu koperasi JMHS juga melakukan transaksi dengan perusaan ritel yang bermitra dengan JMHS. Perusahaan ritel yang selama ini bermitra dengan JMHS adalah PD. Dian Niaga. Pembayaran oleh PD. Dian Niaga kepada koperasi JMHS dilakukan dengan cara transfer dengan kesepakatan $50 \%$ pembayaran dimuka sebelum panen raya berlangsung dan $50 \%$ sisanya dibayar setelah madu sudah tersedia dan siap dikirim.

Biaya yang dikeluarkan oleh otlet penjualan rumah madu berupa modal pembelian madu dan biaya pengemasan seperti pembelian kemasan botol dan cerigen, alat segel, lakban,label, gunting, kardus dan spidol. Modal pembelian madu berasal dari hasil keuntungan madu sebelumnya sebesar 150 juta. Madu yang telah dikemas kemudian dipasarkan langsung untuk memenuhi kebutuhan konsumen akhir. Rata-rata konsumen akhir membeli madu dengan kemasan cerigen kecil $500 \mathrm{ml}$ seharga Rp. 100.000 dan melakukan pembayaran dengan cara tunai maupun transfer jika lokasi konsumen berada diluar kota.

\section{Aliran Informasi}

Jenis informasi yang disediakan pemburu madu adalah lokasi pengambilan madu, volume hasil panen madu dan kualitas madu. Lokasi pengambilan madu oleh pemburu memiliki lokasi yang berbeda-beda dan tidak ditentukan oleh mitra. Lokasi 
pengambilan madu oleh pemburu di Kecamatan Batulanteh biasanya dikawasan hutan maupun gunung yaitu pada area gunung Pasan, tiu jolo, talaga, labakung, gunung Kemoran Ai, brang po, kokar petung, brang kelis, pelepat indah, pelepat nilam, hutan sagara barat semongkat. Lokasi pengambilan madu di Kecamatan Lantung berada sekitar kawasan hutan labantan, tewan, brang tenga, laboto, talemir, gunung lebakung (lantung barat) dan gunung babalo (lantung timur). Sedangkan lokasi pengambilan madu di Kecamatan Empang berada pada kawasan pegunungan olat malang, rabangkang, sudi dan ai cente. Aliran informasi JMHS disajikan dalam Gambar 5 berikut
Rata-rata hasil panen madu pemburu berkisar antara 30-40 botol dalam satu kali panen dan pada saat musim panen raya. Selain itu pemburu juga menginformasikan mengenai kualitas madu hasil panen serta kekentalan dan warna madu yang didapatkan. Informasi yang dibutuhkan oleh pemburu madu adalah harga pembelian oleh jaringan, pemberian bantuan alat, platihan dan jaminan pasar. Aliran informasi di tingkat pemburu hanya terbatas pada harga sedangkan informasi mengenai pelatihan, dan bantuan alat tidak tersalur dengan baik.

Jenis informasi yang diketahui oleh ketua kelompok adalah harga pembelian ditingkat pemburu, lokasi pengambilan madu, kualitas madu dan volume hasil panen yang akan dijual oleh pemburu.

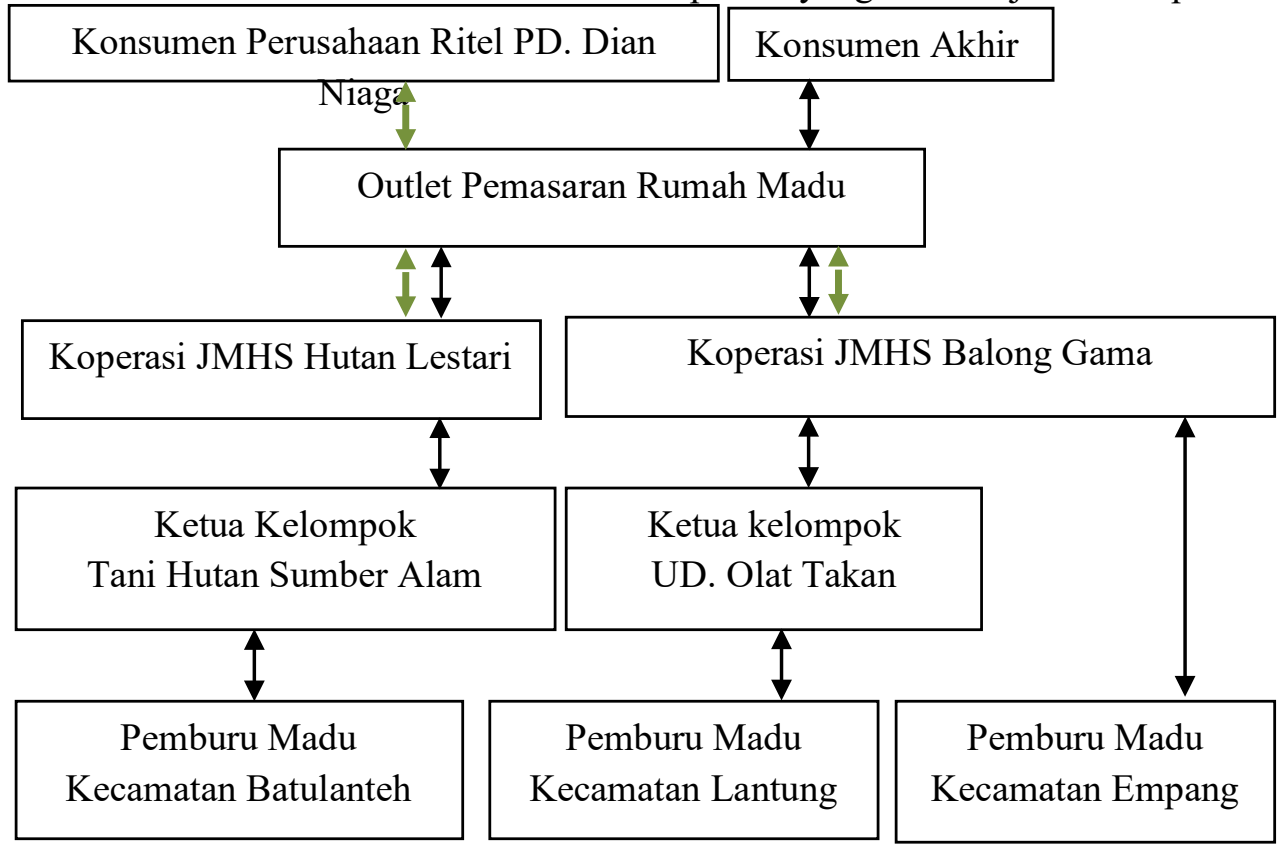

\footnotetext{
Keterangan :

$\longleftrightarrow$ : Aliran informasi dengan jaringan

: Aliran informasi dengan perusahaan mitra PD.Dian Niaga
}

Gambar 5. Aliran informasi rantai pasok JMHS

Jenis informasi yang dibutuhkan ketua 
kelompok adalah harga pembelian oleh koperasi JMHS, perkiraan waktu pengambilan madu oleh koperasi JMHS, volume kuota permintaan madu JMHS, standar kualitas madu JMHS dan kegiatan pelatihan yang diadakan oleh JMHS. Ketua kelompok mencari informasi melalui media telekomunikasi yaitu melalui telepon, pesan singkat maupun whatshapp grup. Aliran informasi di tingkat ketua kelompok terbatas pada harga saat transaksi sedangkan kebutuhan pasar dan perkiraan volume pasokan dari daerah lain tidak dapat diketahui secara transparan.

Informasi yang diketahui oleh koperasi JMHS adalah harga kesepakatan pembelian oleh jaringan, harga pasar nasional yang diperoleh dari jaringan madu hutan Indonesia, volume permintaan perusahaan mitra dan konsumen, standar kualitas dan mutu madu yang diminta oleh mitra, memberikan pelatihan secara berkala dengan anggota JMHS dan pemberian bantuan alat panen maupun alat tiris madu. Informasi yang dibutuhkan oleh koperasi JMHS adalah waktu panen madu, stok madu yang tersedia, lokasi pengambilan madu dan kualitas serta kandungan kadar air madu. Koperasi JMHS mencari dan member informasi melalui media telekomunikasi seperti telepon, pesan singkat maupun whatshapp grup. Aliran informasi pada tingkat koperasi JMHS dilakukan dengan pola kemitraan. Seluruh informasi yang dibutuhkan dan disediakan oleh mitra baik anggota jaringan maupun perusahaan diterima oleh JMHS. Keterbukaan informasi juga ditunjang oleh adanya tenaga Pembina yang berperan sebagai penyuluh dan pengawas dari JMHS. Anggota kelompok segala informasi mengenai bantuan alat dari JMHS, teknik dan sistem panen yang disarankan oleh JMHS sampai kepada harga pembelian dan jaminan pasar. Sementara perusahaan memperoleh informasi tentang semua hal yang berkaitan dengan anggota jaringan mitra dari pemburu, ketua kelompok, perusahaan mitra hingga outlet pemasaran Rumah Madu.

Jenis informasi yang diketahui oleh outlet pemasaran Rumah Madu adalah permintaan konsumen akhir, jenis madu yang banyak dicari oleh konsumen dan bentuk kebutuhan madu yang diminati oleh konsumen. Jenis informasi yang dibutuhkan oleh Rumah Madu adalah harga pengambilan madu pada koperasi JMHS dan stok madu yang tersedia. Outlet pemasaran Rumah Madu mencari informasi dengan menghubungi langsung koperasi JMHS melalui media komunikasi seperti handphon, pesan singkat, whatshapp grup dan media social lainnya. Pada dasarnya informasi mengenai harga madu yang dibeli oleh Rumah Madu kepada koperasi JMHS sudah merupakan kesepakatan jaringan. Aliran informasi pada organisasi JMHS Berbeda dengan aliran produk dan aliran finansial. Aliran informasi mengalir secara timbal balik mulai dari pemburu madu hingga konsumen akhir begitu pula sebaliknya. Pemburu madu menginformasikan mengenai kuantitas dan kualitas hasil panen madu kepada JMHS yang nantinya akan dijual ke konsumen mitra maupun konsumen akhir. Sedangkan JMHS memberik an informasi mengenai harga sesuai dengan harga yang disepakati bersama berdasarkan harga pasar.

Penelitian ini sejalan dengan penelitian Rasoki (2016), yang meneliti 
mengenai rantai pasok bawang merah di Kabupaten Berebes. Menurut Rasoki (2016) aliran informasi mengalir secara timbal balik yaitu mengenai kuantitas dan harga bawang merah yang diperoleh dari sesama petani sebagai acuan dalam proses tawar menawar. Namun, informasi yang diperoleh petani belum sepenuhnya sesuai dengan perubahan pasar. Keterbatasan informasi pasar ini dapat menyebabkan petani tidak mampu mengatur penawarannya untuk mendapatkan harga yang lebih menguntungkan (Irawan 2007).

\section{SIMPULAN DAN SARAN}

\section{Simpulan}

Pola distribusi rantai pasok JMHS pada ketiga aliran utama belum berjalan dengan baik. Pada aliran produk, proses pengiriman madu dan kualitas madu yang dibutuhkan konsumen belum terpenuhi dengan baik dikarenakan oleh madu yang dipanen tergantung musim. Sehingga waktu pengiriman tidak dilakukan setiap waktu. Aliran finansial JMHS sudah berjalan dengan baik, harga yang berlaku merupakan harga yang berasal dari JMHS hanya saja sistem pembayaran skala besar pada saat musim panen raya yang mengakibatkan pembayaran madu tidak langsung diterima secara keseluruhan. Sedangkan aliran informasi pada rantai pasok JMHS memiliki kelemahan yaitu ketersediaan informasi yang minim akibat lokasi anggota kelompok berada didaerah kawasan hutan.

\section{Saran}

Jaringan Madu Hutan Sumbawa (JMHS) diharapkan dapat melakukan perencanaan kolaboratif yang baik dengan anggota JMHS terutama pemburu madu mitra, dengan cara memberikan informasi manajemen kontrol yang jelas, agar anggota JMHS mampu mendistribusikan produk dengan baik, aktifitas finansial berjalan lancar dan informasi tersalurkan dengan baik.

\section{DAFTAR PUSTAKA}

Chopra S, Meindl P. 2007. Supply Chain Management : Strategy, Planning and Operation. Third Edition. New Jersey (US) : Pearson Education, Inc.

FAO. 2017. Volume Export dan Import Madu di Indonesia Tahun 20132016. Hhtp://www.faostat.fao.org. Diakses 11 Desember 2017.

Hadisoesilo, S. 2001. Keanekaragaman Spesies Lebah Madu Asli Indonesia. Biodiversitas, 2:123128.

Hilmi, M., N. Bradbear, dan D. Mejia. 2011. Beekeeping and Sustainable Livelihoods. Food and Agriculture Organization of the United Nations. Rome.

Indrajit RE, Djokopranoto RE. 2002. Konsep Manajemen Supply Chain Cara Baru Memandang Mata Rantai Penyediaan Barang. Jakarta (ID) : Grassindo.

Irawan B. 2007. Fluktuasi Harga, Transmisi Harga, dan Marjin Pemasaran Sayuran dan Buah. Analisis Kebijakan Pertanian. 5(4):358-373.

Jaringan Madu Hutan Indonesia. 2017. Data Produksi Anggota Jaringan Madu Hutan Indonesia 20132017. JMHI. Riak Bumi 
Jaringan Madu Hutan Sumbawa. 2017.

Data Produksi Madu Jaringan

Madu Hutan Sumbawa pada

Tahun 2015-2017. JMHS.

Sumbawa.

Julmansyah 2010. Madu Hutan

Menekan Deforestasi. Jalan Lain

Konservasi DAS dan Adaptasi

Perubahan Iklim. Jaringan Madu

Hutan Sumbawa (JMHS). Pondok

Madu Rakyat Desa Batudulang,

Kecamatan Batulanteh.

Moko, H. 2008. Mengalangkan Hasil Hutan Bukan Kayu Sebagai

Produk Unggulan. Informasi

Teknis. Balai Besar Penelitian

Bioteknologi dan Pemuliaan

Tanaman Hutan.

Murtidjo, B. A. 1991. Memelihara Lebah Madu. Kanisius.

Yogyakarta.

Novandra, A., dan I. M. Widnyana. 2013. Peluang Pasar Produk Perlebahan Indonesia. Balai Penelitian Teknologi Hasil Hutan Bukan Kayu.

Nurmalina Rita. 2014. Pemasaran Konsep dan Alikasi. IPB Press. Bogor

Rasoki, Timbul. 2016. Rantai Pasok Bawang Merah di Kabupaten Berebes, Jawa Tengah. [Thesis]. Program Pascasarjana. Institut Pertanian Bogor. Bogor.

Syakur, Moh A. 2017. Analisis Rantai Pasokan (supply chain) Daging Sapi dari Rumah Pemotongan Hewan sampai Konsumen di Kota Surabaya. Sains Peternakan, 15(2):52-58. 


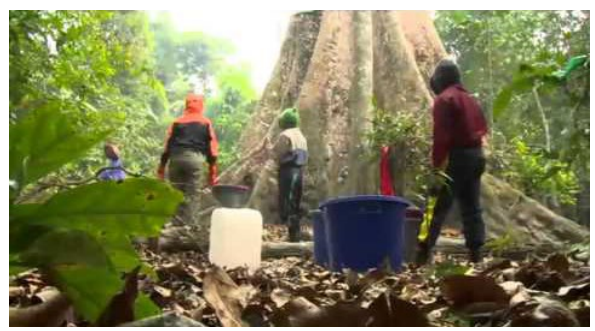

Pemburu Madu di Lokasi Panen

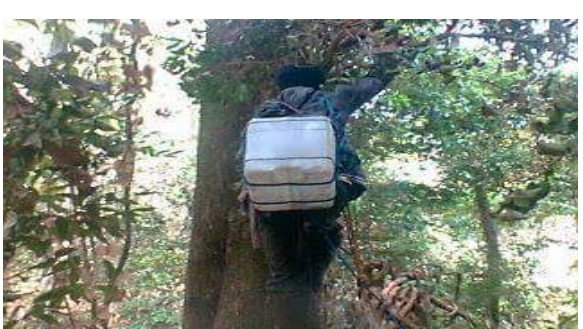

Cara Pemburu Mengambil Madu

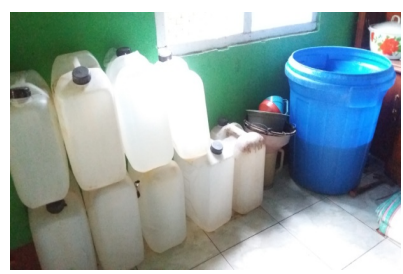

Penampungan Madu Ketua Kelompok

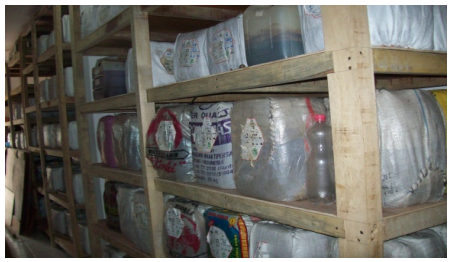

Ruangan Pengurang Kadar Air

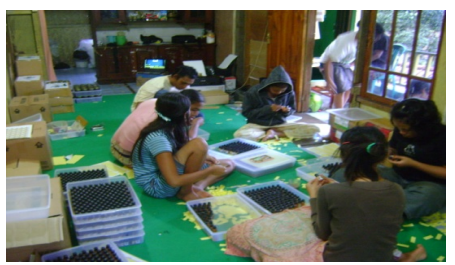

Pengemasan di Rumah Madu

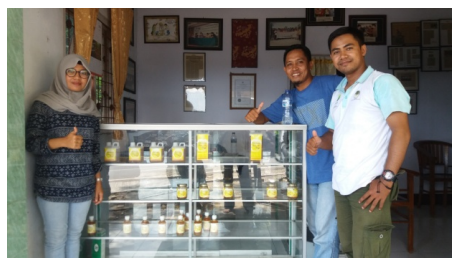

Rumah Madu dan Produk

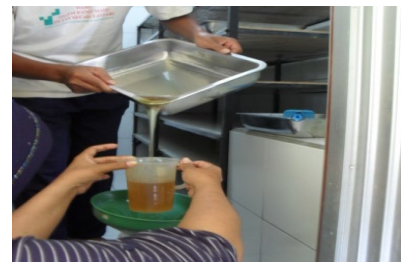

Penyaringan

Sistem Tiris

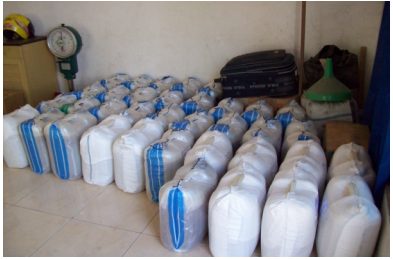

Madu Siap Kirim ke Perusahaan Mitra

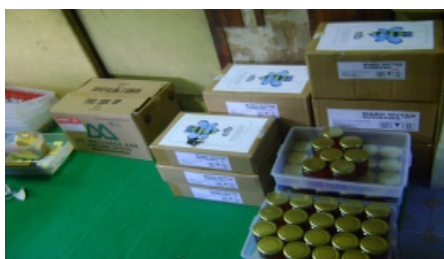

Produk JMHS

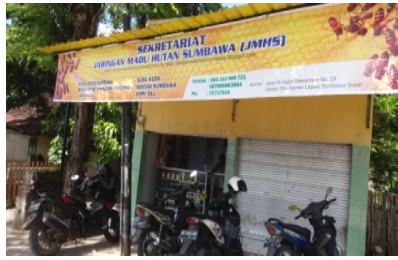

Outlet Rumah Madu

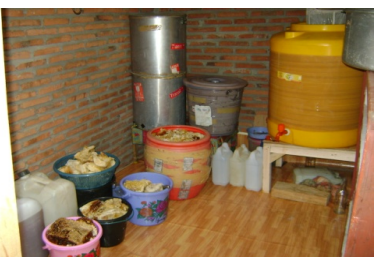

Penampungan

Madu Koperasi

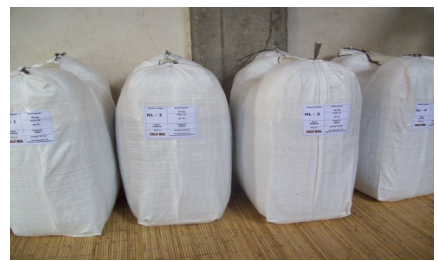

Kode Panen

Madu

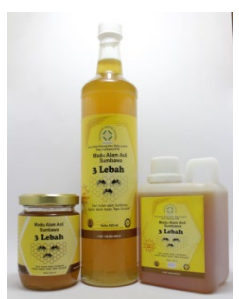

Produk JMHS

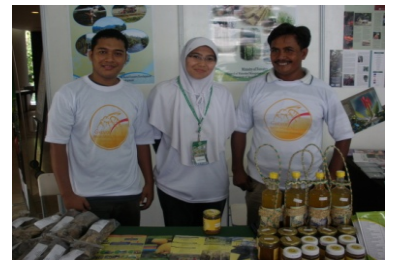

Kegiatan Bazar JMHI 
